\title{
Pleuropulmonary complications of pancreatitis
}

\author{
M ICHAEL D. K A Y E \\ From Sully Hospital, Penarth, Glam.
}

\begin{abstract}
Pancreatitis, in common with many other upper abdominal diseases, often leads to pleuropulmonary complications. Radiological evidence of pleuropulmonary abnormality was found in $55 \%$ of 58 cases examined retrospectively. The majority of such abnormalities are not specific for pancreatitis ; but a particular category of pleural effusions, rich in pancreatic enzymes, is a notable exception. A patient with this type of effusion, complicated by a spontaneous bronchopleural fistula and then by an empyema, is reported. The literature relating to pancreatic enzyme-rich pleural effusions (pathognomonic of pancreatitis) is reviewed. Of several possible mechanisms involved in pathogenesis, transdiaphragmatic lymphatic transfer of pancreatic enzymes, intrapleural rupture of mediastinal extensions of pseudocysts, and diaphragmatic perforation are the most important. The measurement of pleural fluid amylase, at present little employed in this country, has considerable diagnostic value. Enzyme-rich effusions are more commonly left-sided, are often blood-stained, are frequently associated with pancreatic pseudocysts, and-if long standing-may be complicated by a bronchopleural fistula.
\end{abstract}

While the association of pleuropulmonary abnormalities with acute upper abdominal disease is well known, the combination of pleural effusion with pancreatitis is relatively uncommon. A proportion of these effusions are rich in pancreatic enzymes, a fact well recognized in the United States and on the Continent but not, judging by the literature, in Britain. Early reports by Phillips (1901), Alivisatos (1920), Clairmont (1926), and de Takats and Mackenzie (1932) referred to pleural effusions in pancreatitis, but it was not until Werner's article, in 1942, describing the significance of pleural fluid amylase, that the unusual nature of these effusions was appreciated.

Though the majority are associated with pancreatic pseudocysts, Judd, Mattson, and Mahorner (1931), in a comprehensive review of the early literature on pseudocysts, made no reference to pleural effusions. Likewise, Bickford (1948), who described two patients with traumatic pseudocysts and pleural effusions, was unable to find any instance of pleural effusion in 134 cases of pancreatic pseudocysts which he collected from the literature. A single case report, of a patient with an enzyme-rich pleural effusion following acute pancreatitis, is therefore felt to be justified. In addition, an attempt has been made to estimate the frequency of pleuropulmonary lesions, and in particular pleural effusions, by reviewing the chest

'Present address: Medical Unit. Cardiff Royal Infirmary radiographs of patients admitted to hospital with pancreatitis.

\section{CASE REPORT}

J. W. aged 56, a labourer, was well until the morning of 1 January 1966, when, while at work, he developed epigastric pain which radiated through to the back. This steadily increased in severity. He vomited and was admitted to Cardiff Royal Infirmary. He gave no history of previous abdominal pain. On admission he was in severe pain with a temperature of $34.2^{\circ} \mathrm{C}$., pulse rate of $60 /$ minute, and B.P. $120 / 65 \mathrm{~mm}$. Hg. There was epigastric tenderness and guarding. A clinical diagnosis of acute pancreatitis was confirmed by a serum amylase level in excess of 3,200 Somogyi units $/ 100 \mathrm{ml}$. (normal $80-180$ units $/ 100 \mathrm{ml}$.). The chest radiograph on admission was normal. Other investigations were non-contributory, except for a glucose tolerance test some days later which showed a diabetic curve (fasting level, $120 \mathrm{mg}$. $/ 100 \mathrm{ml}$.; 1 hour, 268 mg./100 ml.; $1 \frac{1}{2}$ hours, $260 \mathrm{mg} . / 100 \mathrm{ml}$.). There was no glycosuria.

He was treated conservatively with intravenous fluids containing propantheline bromide (Pro-Banthine), tetracycline, and Trasylol (kallikrein inactivator). He steadily improved and by late January was entirely free of symptoms, though there was a persistent low-grade pyrexia, and the serum amylase remained elevated (800 Somogyi units $/ 100 \mathrm{ml}$. on 26 January). The suspicion that he might have a pancreatic pseudocyst was supported by radiological examinations carried out on 24 January. The chest 


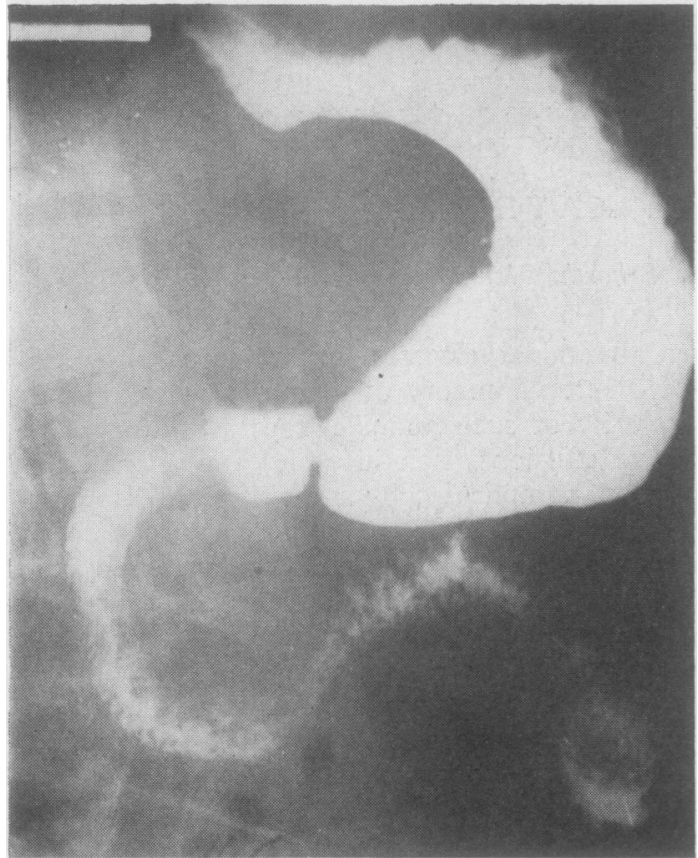

FIG. 1. Barium meal 24.1.66. Posterior pseudocyst and widening of duodenal loop. radiograph showed a raised left hemidiaphragm while a barium meal demonstrated a fixed hiatus hernia with reflux and probable widening of the duodenal loop. There was also anterior displacement of the stomach, whose posterior surface was indented by a mass lying between it and the vertebral column (Fig. 1). Operative exploration was not felt to be justified, and he was discharged on 27 January.

A follow-up barium meal on 15 April 1966 showed that the mass previously noted had disappeared, but that a small left pleural effusion had developed. Over the next few weeks he became increasingly short of breath and was readmitted to hospital on 24 May. $\mathrm{He}$ was ill and had the signs of a large left pleural effusion (Fig. 2). Four litres of clear yellow fluid were aspirated on the evening of his admission, subsequent aspiration yielding a further 4 litres approximately of similar fluid. This was predominantly lymphocytic, and sterile on culture. Neither malignant cells nor acidfast bacilli were found. Pleural biopsy was unhelpful, revealing only macrophages and young fibrous tissue. On 23 June he was discharged, somewhat improved, his last pleural aspiration having been carried out on 17 June.

The effusion re-accumulated. In mid-July he began to expectorate copious amounts of clear yellow fluid. The chest film of 3 August 1966 showed a left hydropneumothorax (Fig. 3), indicating the development of a bronchopleural fistula. The spontaneous origin of the latter was supported by several films taken after

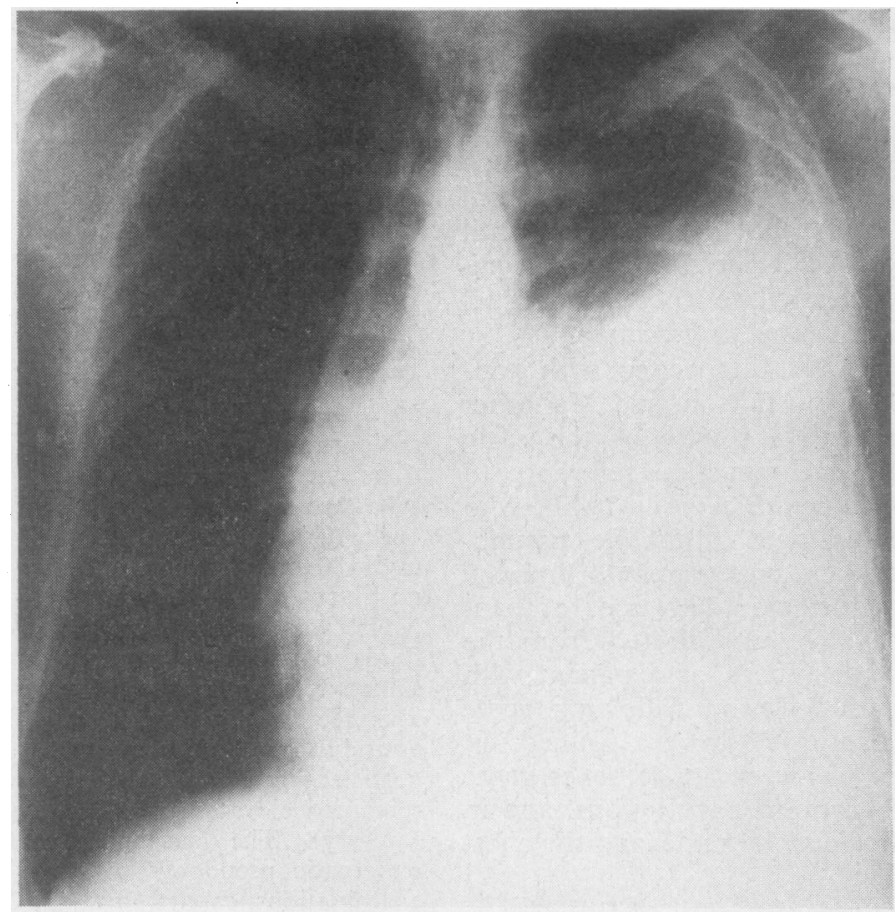

FIG. 2. 24.5.66. Chest radiograph shows left pleural effusion. 


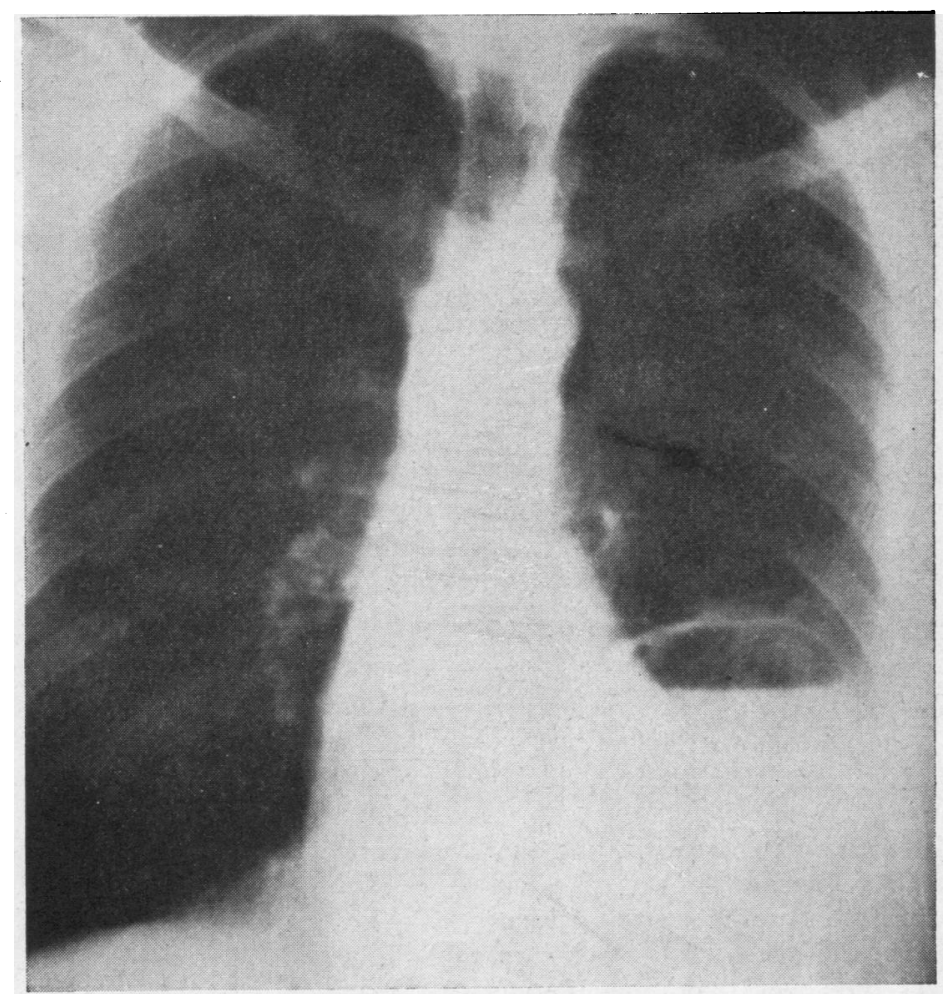

FIG. 3. 3.8.66. Chest radiograph shows left hydropneumothorax.

his last previous aspiration, showing fluid but no air in the left pleural cavity.

Because of this development he was transferred to Sully Hospital on 5 August 1966 . He was breathless, expectorating substantial amounts of rather thin yellowish sputum and complaining of aching pain in the left lower chest. Physical examination revealed the signs of a left pleural effusion but was otherwise negative. Investigations performed at the time of admission included haemoglobin $13.3 \mathrm{~g} . / 100 \mathrm{ml}$., W.B.C. 9,000, liver function tests normal, and serum amylase 180 Somogyi units $/ 100 \mathrm{ml}$., i.e., at the upper limit of normal.

Left pleural aspiration was carried out on 9 August. Clear yellow fluid was obtained. Its protein content was $1.3 \mathrm{~g} . / 100 \mathrm{ml}$. Enzyme determinations on the fluid showed lactic dehydrogenase 0 , amylase 45,000 Somogyi units/100 ml., lipase 4.6 Sigma-Tietz units, and tryptic activity to a dilution of 1 in 16 .

'Pleural biopsy revealed merely organizing granulation tissue. Following aspiration a few millilitres of propyliodone (Dionosil) were injected into the left pleural cavity. Radiographs taken at intervals thereafter further confirmed the existence of a bronchopleural fistula in that radio-opaque material was visible in the bronchial tree. They also provided evidence that there was no breach of diaphragmatic continuity, serial films up to three days after injection showing a persistence of propyliodone above the diaphragm but none at any time beneath it (Fig. 4).

Over the next few days he deteriorated. He felt ill and was febrile, and his sputum became grossly purulent. At further pleural aspiration on 16 August thick fluid, greyish in colour and containing numerous pus cells, was obtained. Staphylococcus aureus was cultured from this emphysema fluid and from his sputum. He was treated with ampicillin and cloxacillin, to which the organism was sensitive, and on 19 August an intercostal tube was inserted into the left pleural cavity under local anaesthesia. His progress thereafter was good. The tube was gradually shortened and finally removed on 11 October 1966, after which the sinus between the pleural cavity and the chest wall rapidly closed. He has remained well since, and his chest radiograph has returned almost to normal.

\section{CHEST RADIOGRAPHIC ABNORMALITIES IN PANCREATITIS}

The notes of all patients admitted with a diagnosis of acute pancreatitis to the United Cardiff Hospitals during the years 1960 to 1965 were examined. In those patients in whom the clinical 


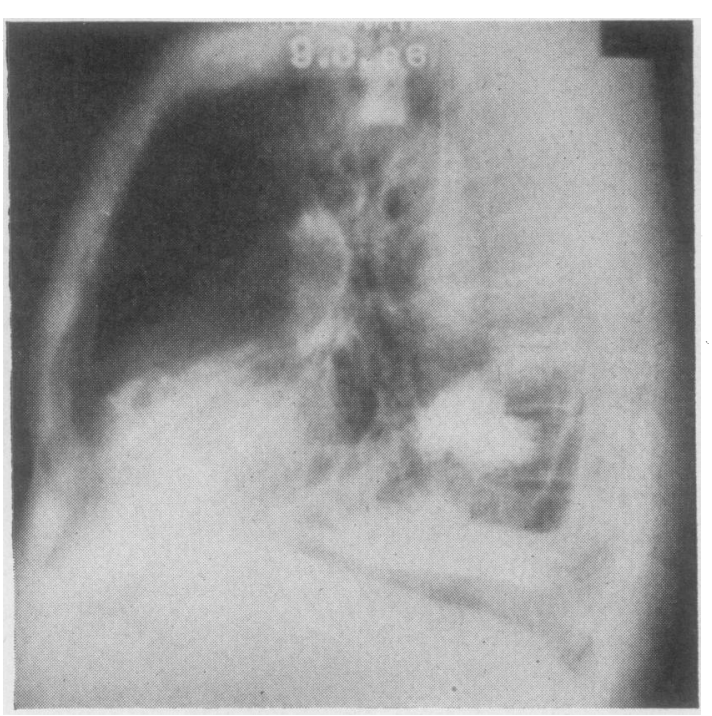

FIG. 4. 9.8.66. Left pleurogram. No diaphragmatic perforation demonstrable.

picture was consistent with pancreatitis, and there was confirmatory evidence of raised serum amylase and/or laparotomy or necropsy evidence of acute pancreatitis, the chest radiographs were examined whenever they were available. Patients whose films were unobtainable, or were taken during the four weeks following a major opera:tion, or in whom there was any other cause fof radiological abnormalities in the chest, werexcluded. There remained 58 patients who had has chest radiographs during 62 admissions for acute pancreatitis. In them the findings were as follows: normal chest radiographs, 28 ; right sid $\overrightarrow{6}$ abnormal, 9 ; left side abnormal, 13 ; bilaterally. abnormal, 12 ; total abnormal, 34 .

Abnormalities observed could be grouped unders the four main headings of raised hemidiaphragm pleural effusion, basal linear shadows, and pleurato reaction (defined as abnormal radiological shadowi ing in the lower zone and contiguous with the diaphragm). An example of these abnormalities is shown in Figure 5.

They occurred as follows:

Raised hemidiaphragm

$\begin{array}{lr}\text { Right } & 10 \\ \text { Left } & 7 \\ \text { Bilateral } & 3 \\ \text { Total } & 20 \\ \text { Pleural reaction } & \\ \text { Right } & 4 \\ \text { Left } & 8 \\ \text { Bilateral } & 4 \\ \text { Total } & 16\end{array}$

Basal linear shadows Right $\quad 3 \vec{\bullet}$ Left Bilateral Total Pleural effusions

Right

Left

Bilateral

Total

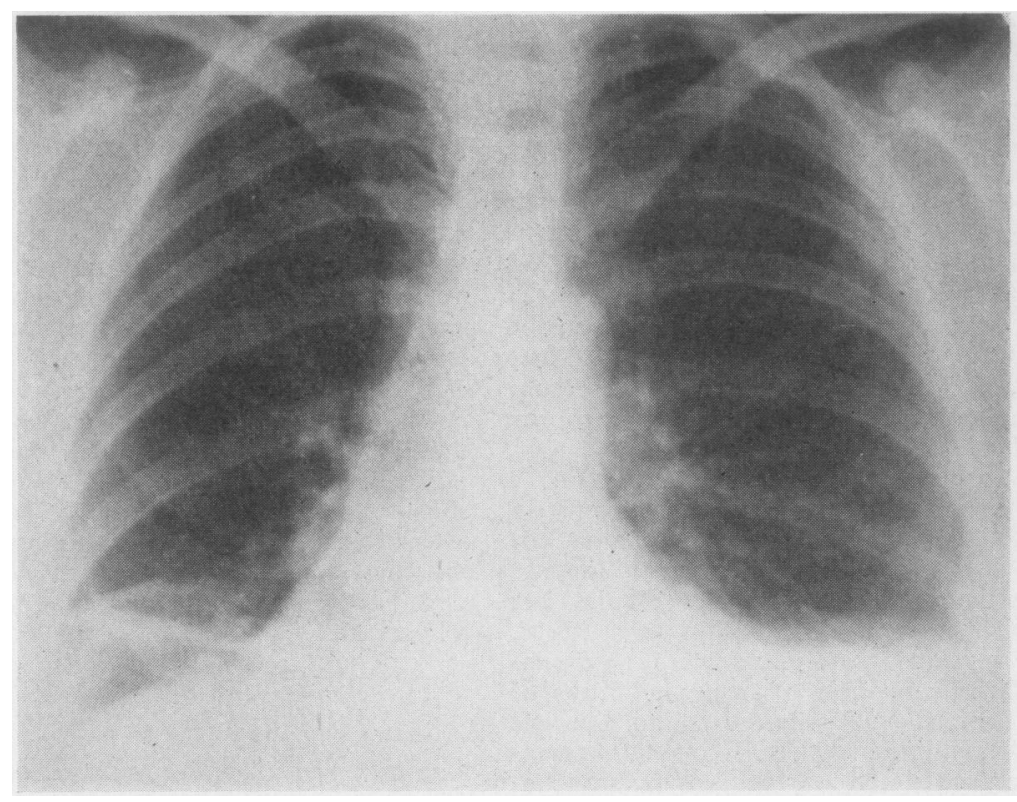

FIG. 5. An example of non-specific pleuropulmonary disease in pancreatitis. Raised left hemidiaphragm with pleural reaction. Linear shadowing right lower zone. 
Although the numbers are small, it is noteworthy that only in the cases of pleural effusion, all five instances of which occurred on the left side, was there any evidence of greater involvement of one hemithorax than the other.

\section{DISCUSSION}

It is well recognized that chest radiographic abnormalities occur quite frequently in the course of acute upper abdominal disease, particularly subphrenic abscess (Ochsner and de Bakey, 1938). It is probably not surprising, therefore, that acute inflammatory processes of the pancreas, an organ closely related to the diaphragm, should be associated with pleuropulmonary abnormalities, the radiological features of which were first described by Hultén (1928) and later by Case (1940). Attempts to estimate the frequency of such abnormalities (Lipp and Aaron, 1950; Felson, 1951 ; Coffey, 1952 ; Meyers, Brown, Boone, and Henderson, 1955 ; Bockus, Kalser, Roth, Bogoch, and Stein, 1955 ; Stein, Kalser, Sarian, and Finkelstein, 1959; Hammarsten, Honska, and Limes, 1959 ; Roseman, Kowlessar, and Sleisenger, 1960 ; Sharafaev, 1961 ; Fishbein, Murphy, and Wilder, 1962 ; Classen and Hooper, 1964) have yielded widely differing results. These differences can be attributed, at least in part, to the fact that the criteria employed for the diagnosis of pancreatitis, for the assessment of pulmonary abnormality, and for the exclusion of patients in whom other factors (e.g., operation) might be relevant, were not the same; nor was there uniformity in the descriptive terms used for the categorizing of abnormalities. In those series which relied upon radiological examination, the recorded frequency of pleuropulmonary abnormality in patients with pancreatitis varied between $14 \%$ and $53 \%$ (as compared with $55 \%$ in the present series). Considering pleural effusion separately, the figures varied between $3 \%$ and $17 \%$ ( $8 \%$ in this series).

Although a prospective study would clearly be needed to obtain true estimates of frequency, there can be no doubt that these abnormalities are common. The majority are not specific for pancreatic disease. Although their nature is not entirely clear, some basal lesions are doubtless the consequence of unrecognized pulmonary infection or infarction. Impairment of diaphragmatic function must be a further factor of importance in pathogenesis. The division of these basal pleuropulmonary lesions into such categories as raised hemidiaphragm, linear atelectasis, pleural reaction, etc., is arbitrary and not very meaningful but of some value for descriptive purposes.
Pleural effusions resulting from such causes as pulmonary infection or infarction are likewise not specifically associated with pancreatitis; but there is substantial evidence for the occurrence of a separate category of pleural effusion, characterized by a big rise of pancreatic enzymes in pleural fluid, which is for practical purposes pathognomonic of pancreatitis. Probably the first to appreciate the significance of pleural fluid amylase was Werner in 1942, since which time it has become increasingly clear that this measurement is most valuable, both in establishing the aetiology of pleural effusions occurring during the course of an attack of acute pancreatitis and, more rarely, in suggesting a diagnosis of pancreatitis, especially the chronic variety, when this had been previously unsuspected.

Although most authors agree that a level of amylase in pleural fluid which is significantly raised above normal and also higher than simultaneous serum values is virtually pathognomonic of a 'pancreatogenic' pleural effusion, Cachin and Battesti (1964) have described a patient whose pleural fluid amylase was very high $(53,000$ Somogyi units $/ 100 \mathrm{ml}$.), yet in whom the pancreas was macroscopically normal at laparotomy, though a biopsy showed minor histological abnormalities. However, no other cause was demonstrated for this effusion, which resolved following laparotomy. Clauss and Wilson (1958) state that raised amylase levels occur in effusions with primary bronchogenic carcinoma and with primary and secondary retroperitoneal tumours invading the thoracic duct, though they do not provide evidence for their view. It is true that Ende (1960), examining 28 pleural effusions in patients with diseases other than pancreatitis, found a significant elevation of amylase in five, each of whom had primary or secondary intrathoracic neoplastic disease, but it must be stressed that this rise was slight only. Ende indicated a possible cause for such a rise when he demonstrated, in one patient with a bronchogenic carcinoma, an elevated level of amylase in hepatic tumour deposits. Others have investigated pleural fluid amylase in patients with effusions unrelated to pancreatitis. For example, Werner (1942), Hammarsten et al. (1959), and Warter, Metais, Weill, and Storck (1962), examining, respectively, 7,12 , and 21 pleural effusions, found the amylase levels in all cases to be within normal limits. Modai, Hazard, and Domart (1965) similarly found a slightly elevated amylase level in only one effusion, secondary to carcinoma, out of 29 examined.

A search of the literature revealed reports, largely by French authors, of 73 patients with 
pleural effusions complicating pancreatitis or pseudocyst or pancreatic trauma (Phillips, 1901; Alivisatos, 1920 ; Clairmont, 1926 ; Werner, 1942 ; Jones, 1944 ; Schiepatti and Vernengo, 1946 ; Gambill, Baggenstoss, van Patter, and Power, 1948 ; Bickford, 1948 ; Gross, Null, and Loeb, 1952; Smith, 1953 ; Byrd and Couch, 1955; Juniper, 1955; Kalser, Roth, and Bockus, 1955 ; Mahaffey, Haynes, Mallams, and DeBakey, 1955 ; Saunders and Lanzkowsky, 1956; Gross and Comfort, 1957 ; Soupault, 1958 ; Hammarsten et al., 1959; Héraud and Guerrin, 1959 ; Langeron, Prévost, and Oudar, 1959 ; Roseman et al., 1960 ; Sharafaev, 1961 ; Bittar, 1962 ; Blumberg and Stein, 1962 ; Goldman, Goldman, and Fleischner, 1962 ; Saubier, Viard, and Termet, 1962 ; Vachon, Guillemin, Braillon, Bady, and Ricca, 1962 ; Vachon, Bady, Tête, and Levrat, 1963 ; Warter et al., 1962; Warter, Moise, Asch, Storck, and Gillet, 1963 ; Cornet, Dupon, and Giraudet, 1963 ; Fontaine, Lang, and Hiebel, 1963 ; Brouet, Chrétien, and Modai, 1964 ; Cachin and Battesti, 1964 ; Miguères, Fabre, Fregevu, and Azais, 1964 ; Farrell and Prillaman, 1964 ; Bergmann, Jacobs, Malaisse, and Thys, 1965 ; Modai et al., 1965; Satrazin, Le Rohelec, Bousquet, Naudy, and Deparis, 1965; Trémolières, Le Quintrec, Lambling, and Carayon, 1965 ; Moreaux, Clot, Mercadier, and Hepp, 1966 ; Warembourg, Lekieffre, Bertrand, and Delbecque, 1966). In 37 of these patients the pleural fluid amylase was demonstrated to be raised, the highest recorded value being 475,000 Somogyi units $/ 100 \mathrm{ml}$. It was normal in three, and not measured in the remaining 33.

These effusions are more commonly left-sided (left 48, right 24, bilateral 8). If those cases in which the pleural fluid amylase was normal, or not measured, are excluded, a predilection for the left pleural cavity remains (left 26 , right 10 , bilateral 1). This must be relevant to pathogenesis, a discussion of which follows.

Of similar relevance must be the frequent association of enzyme-rich pleural effusion with a pancreatic pseudocyst. There was clear evidence of the latter post mortem, at laparotomy, or on radiological grounds in 38 of the 73 cases. In a further two cases pseudocyst was suspected on the clinical finding of a cystic tumour in the left hypochondrium.

It is worth noting that the effusion was bloodstained in 24 of the 73 cases. There was no correlation between the presence, in pleural fluid, of blood and the level of pancreatic enzymes as measured by amylase.
Views on the pathogenesis of these enzyme- $\overrightarrow{\vec{D}}$ containing pleural effusions differ. It is clear that $\overline{0}$ several mechanisms may be involved. These will be considered briefly in turn.

DIRECT CONTACT OF PANCREATIC ENZYMES WITH DIAPHRAGM Harley (1955), in a discussion of 188 is patients with subphrenic abscess, suggested that $\vec{\circ}$ the serous pleural effusions which developed in 48 instances were the consequence of exudation $\vec{\omega}$ from subpleural diaphragmatic vessels which were more than usually permeable due to inflammation $\times$ -in effect, pleural oedema. Since, as he pointed $\underset{\omega}{N}$ out, the diaphragm forms part of the abscess wall, $\omega$ this explanation is probably correct. A similar है situation can be envisaged in pancreatitis. Although, in these circumstances, inflammation is chemical rather than infective, the result (pleural $\overrightarrow{-}$ exudation with the formation of serous effusion) will be the same. However, this mechanism can be relevant only to the non-specific type of pleural effusion. It cannot account for those effusions in which the concentration of pancreatic enzymes is higher than that in the blood.

HAEMATOGENOUS CARRIAGE OF PANCREATIC ENZYMES TO PLEURA The basis for this theory is the occur- $\frac{\triangle}{\mathbb{D}}$ rence, noted towards the end of the last century, of fat necrosis in sites remote from the pancreas $\overrightarrow{0}$ during acute pancreatitis. Balser in 1882 described such fat necrosis in bone marrow and subpericardial fat. Hart (1904) referred to necrosis in perioesophageal, diaphragmatic, parietal pleural, and subcutaneous fat. A somewhat crude experimental analogy was provided by Payr and Martina in $\times$ 1906 when they produced subcutaneous fat $\frac{5}{3}$ necrosis in animals by the intravenous injection of pancreatic debris. More pertinent to the pleura, Schiepatti and Vernengo (1946) were able to produce pleural reaction by the injection, either intra- $\frac{}{\partial}$ venous or into retroperitoneal tissues, of pancreatic $\frac{D}{O}$ enzymes. But, using the intravenous route, they had to employ high concentrations of enzyme $\tilde{N}$ which were rapidly lethal.

Haematogenous transfer of enzymes cannot $N$ account for the greater frequency of left-sided $\omega$ effusions, or for the fact that enzyme concentrations are higher in pleural fluid than in blood. It is difficult, therefore, to accept it as a factor of more than minor importance.

DIRECT MOVEMENT OF FLUID FROM ABDOMEN TO THORAX There are various possibilities:

Transfer of fluid via natural hiati Such hiati are $\stackrel{\mathbb{D}}{\square}$ a necessary consequence of the piercing of the diaphragm by the oesophagus, inferior vena cava, $ᄋ$ 
and aorta. The immediate result of fluid finding its way through these hiati would be the formation of mediastinal collections. Such mediastinal extensions of pseudocysts are well described in pancreatitis (Jones, 1944 ; Edlin, 1951 ; Clauss and Wilson, 1958 ; Poppel, 1959; Moreaux et al., 1966). For pleural effusions to develop in these circumstances, the mediastinal collection must break through the pleura into the pleural space, either by the effect of pressure or, possibly, by pancreatic digestion. Communication between mediastinum and pleural cavity was demonstrated in patients described by Jones (1944) and Moreaux et al. (1966), but such an occurrence is either very rare or very difficult to demonstrate.

Diaphragmatic perforation by a pancreatic pseudocyst This possibility is frequently raised but much less often demonstrated. Some (e.g., Goldman et al., 1962) go so far as to suggest that one may assume the existence of a communication between supra- and sub-diaphragmatic collections in those effusions with a very high amylase content. However, it must be stressed that several patients with such effusions, and without any evidence at laparotomy of pseudocysts or transdiaphragmatic fistulae, have been reported (Sharafaev, 1961; Warter et al., 1962; Cachin and Battesti, 1964). Well-documented examples of perforation are scarce. Poppel (1959) refers to a patient with 'lysis' of the diaphragm but does not give adequate clinical details. Convincing examples of fistula formation between abdomen and thorax have been described by Hunt (1954), Sease (1956), Ruffo, Pironti, and Massa (1960), Dignan (1965), and Bergmann et al. (1965). In all except the case reported by Bergmann the fistula was between the pancreas and the bronchial tree, rather than the pancreas and the pleural cavity. However, these cases demonstrate clearly that diaphragmatic perforation, if uncommon, may follow acute pancreatitis.

Certain features in the clinical picture of the patient described earlier in this report suggest that diaphragmatic perforation might have occurred. Thus, at the time when there was radiological evidence of a pseudocyst, he did not have a pleural effusion, whereas when his left pleural effusion became manifest some weeks later, further radiological examination suggested disappearance of his pseudocyst. The fact that no communication was demonstrated following the intrapleural instillation of radio-opaque material may have been due merely to inadequate technique. The shortcomings of this investigation are exemplified by a patient described by Moreaux et al. (1966), in whom Lipiodol injected intrapleurally did not appear below the diaphragm, yet operative pancreatography shortly afterwards demonstrated a pseudocyst which extended into the posterior mediastinum and communicated with the left pleural cavity.

Transfer of fluid into pleural cavity by transdiaphragmatic lymphatics This hypothesis has much to commend it. The early work of such authors as Bizzozzero and Salvioli (1876), Muscatello (1895), MacCallum (1903), Bartels (1909), and Florey (1927) established the existence of numerous lymphatic vessels joining the lymphatic networks of the superior (subpleural) and inferior (subperitoneal) surfaces of the diaphragm, the peritoneal mesothelium overlying the latter being separated from the endothelium of the lymphatic vessels by only a thin fenestrated basement membrane. It is easy to imagine, therefore, that fluid, with its various constituents, lying in relation to the inferior aspect of the diaphragm, might be transferred to the subpleural lymphatic plexus. In most mammals these lymphatics drain into the right lymph duct via internal mammary and anterior mediastinal nodes, and into the thoracic duct via posterior efferents (Bolton, 1921 ; Higgins and Graham, 1929).

The lymphatic transfer of substances from the abdomen to the thorax is well supported experimentally. MacCallum, in 1903, demonstrated staining of anterior mediastinal nodes with carmine following the intraperitoneal injection of the latter in dogs. The rapidity of transfer of particulate matter was shown by Cunningham (1922), who found that sheep's red cells, filtered lamp black, and unfiltered carmine particles appeared in the anterior mediastinal nodes of cats only three minutes after intraperitoneal injection. Similar findings were obtained in dogs by Lemon and Higgins (1929). In man, outlining of intrathoracic lymph nodes with radio-opaque material (thorium dioxide) occurs following its intraperitoneal injection (Menville and Ané, 1934). Of more immediate relevance to pancreatitis, Perry (1947) injected intraperitoneally into rats a mixture of graphite and pancreatin. He found that in these animals, killed between 18 and 48 hours later, there were areas of fat necrosis in the thoracic cavity, and that such areas corresponded to lymphatic channels, as delineated by graphite. One may accept, then, that pancreatic enzymes released during pancreatitis, lying in the peritoneal cavity or alternatively in high concentration in a pancreatic 
pseudocyst which is limited in one direction by the diaphragm, may readily reach the thorax by the lymphatic route. Moreover, the lymphatic drainage of pancreatic enzymes has been demonstrated in health as well as in disease (Dumont, Doubilet, and Mulholland, 1960).

How enzymes pass from the subpleural lymphatics into the pleural cavity is uncertain, but it is possible that spaces between mesothelial cells may be produced by stretching, such as occurs during respiratory movement (Allen and Vogt, 1937). That substances do pass from subpleural lymphatics into the pleural cavity is supported by observations that materials such as protein and India ink, injected into the ascitic fluid of patients with ascites and hydrothorax complicating cirrhosis, or with Meigs' syndrome, rapidly appear in pleural fluid in a concentration higher than that reached in blood (e.g., Meigs, Armstrong, and Hamilton, 1943).

In pancreatitis, enzymes may reach the pleural cavity merely by causing an intense chemical inflammation, and hence increasing the permeability of lymphatics through which they travel. If lymphatic obstruction results from inflammation and fat necrosis in and around lymphatic channels, this would be a further factor tending to promote the movement of fluid and enzymes into the pleural space. In this connexion, Courtice and Steinbeck (1951) have shown that in ascitic rats ligation of retrosternal lymphatics is followed by the development of pleural effusions. And, indeed, the invasion of intrathoracic lymph nodes, particularly by malignant tissue, is a frequent cause of pleural effusion.

In summary, several mechanisms may be responsible for the development of an enzymerich pleural effusion in pancreatitis. The movement of enzymes into the pleural cavity by a lymphatic route would appear to be of considerable importance. Occasionally, there is a demonstrable communication either between a subdiaphragmatic pseudocyst and the pleural cavity or between the mediastinal extension of a pseudocyst and the pleural cavity.

The striking predilection of enzyme-rich effusions for the left pleural cavity may be largely explicable on simple anatomical grounds, since the pancreas is more intimately related to the left hemidiaphragm than to the right. A similar relationship holds for fluid collections arising from the pancreas. Therefore, effusions, whether formed by lymphatic transfer or by diaphragmatic perforation, might be expected more frequently on the left side. This preponderance of left-sided effusions, even in the absence of pseudocyst, would suggest that the transdiaphragmatic lymphatic transfer of free peritoneal fluid formed during pancreatitis is a factor of relatively minor importance in pathogenesis. In Meigs' syndrome, in which there is good evidence that lymphatic transfer is essential to the development of pleural fluid, effusions are usually right-sided (Meigs et al., 1943 ; Hammouda, 1967).

Finally, bronchopleural fistula is perhaps the least common of all the pulmonary complications

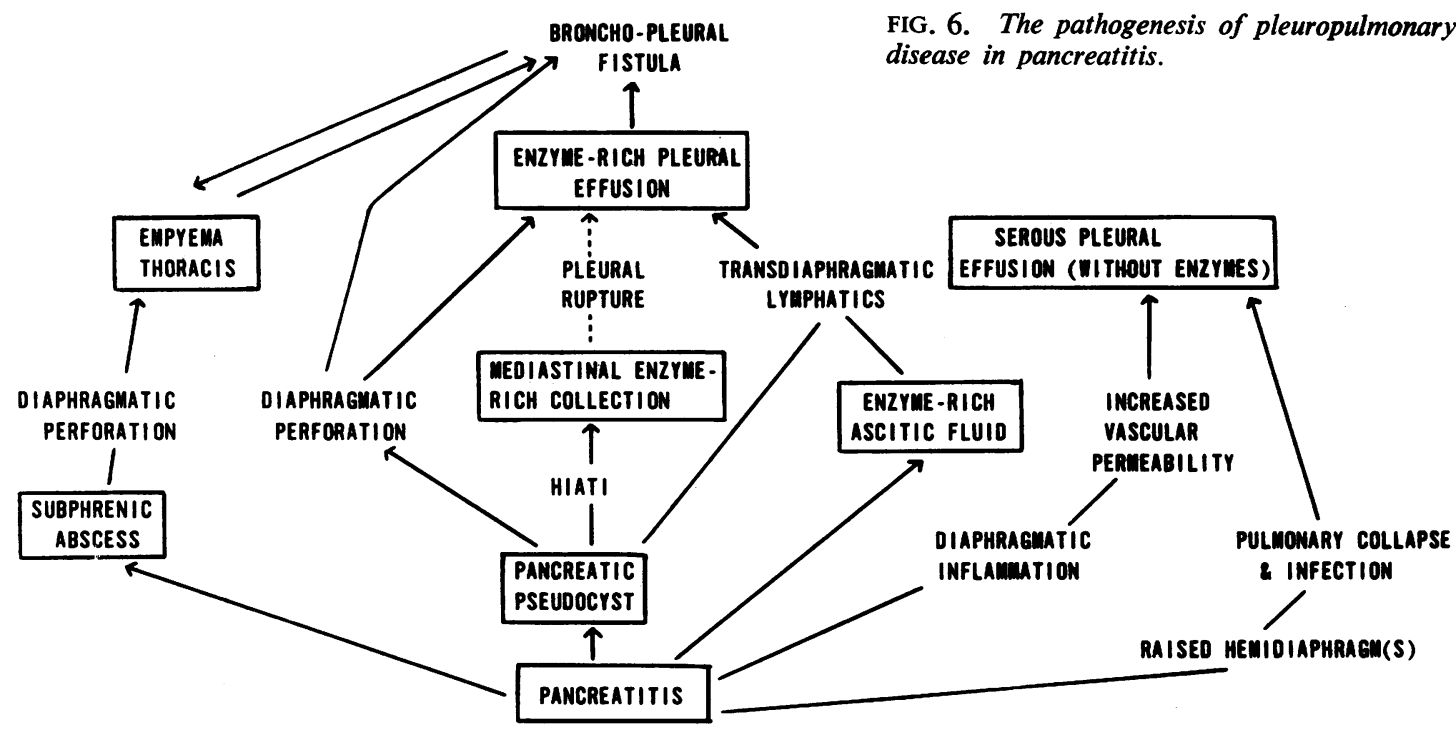

FIG. 6. The pathogenesis of pleuropulmonary disease in pancreatitis. 
of acute pancreatitis. As mentioned earlier, several examples of pancreatico-bronchial fistula have been described (Hunt, 1954 ; Sease, 1956; Ruffo et al., 1960; and Dignan, 1965). In these patients pancreatico-bronchial fistula followed the blocking off of an external pancreatic fistula which had developed after laparotomy. Pleural effusion was a relatively inconspicuous feature and, where present, was not shown to be enzyme-rich. The patient reported above differs, therefore, in several respects. He did not have an external pancreatic fistula. His pleural effusion was large and proved to be rich in pancreatic enzymes. As far as could be determined, it was not accompanied by diaphragmatic perforation. It was present for four months before the development of bronchopleural fistula. The latter, it is suggested, was the consequence of digestion of pulmonary tissue, with overlying visceral pleura, by pancreatic enzymes.

Figure 6 illustrates diagrammatically the ways in which the various pleuropulmonary complications of pancreatitis may arise. Chylothorax, a rare accompaniment of chylous ascites associated with pancreatic pseudocyst (Traquair, 1946; Evans, 1960), has not been considered.

I am greatly indebted to Dr. G. S. Kilpatrick, under whose care this patient was in Sully Hospital, for much helpful advice and criticism in the preparation of this paper. I am grateful also to Dr. J. Slamen, who translated papers from Russian and German; to Miss A. Trott, for secretarial assistance ; to Mr. F. Midgeley, Department of Photography, Sully Hospital ; and to Mr. R. Marshall, Department of Medical Illustration, Cardiff Royal Infirmary.

\section{REFERENCES}

Alivisatos, A. S.(1920). Pancreas polykystique. Kystes rompus dans l'abdomen et pénétration du contenu dans la plèvre droite. Bull. Soc. $m^{\prime} d$. Hôp. Paris, 44, 1181.

Allen L., and Vogt, E. (1937). Mechanism of lymphatic absorption from serous cavities. Amer. J. Physiol., 119, 776.

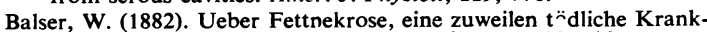
heit des Menschen. Virchows Arch. path. Anat., 90, 520.

Bartels, P. (1909). Das Lymphgefässystem. Fischer, Jena.

Bergmann, F., Jacobs, E., Malaisse, W., and Thys, J. P. (1965). Fistulation pleurale d'un pseudokyste pancréatique. Acta chir belg. Suppl., 3, 128.

Bickford, B. J. (1948). Traumatic pseudocyst of the pancreas with pleural effusion. Report of two cases. Brit. med. J., 2, 1134.

Bittar, E. E. (1962). Amylase activity in hemothorax associated with pancreatitis. Arch, intern. Med., 109, 601.

Bizzozzero, G., and Salvioli, G. (1876). Sulla struttura delle membrane sierose e particolarmente del peritoneo diaframmatico. G. Accad. Med. Torino, 19, 466.

Blumberg, L., and Stein, L. (1962). Traumatic pancreatitis complicated by enzyme-containing pleural effusion. $S$. Afr. med. J., 36, 189.

Bockus, H. L., Kalser, M. H., Roth J. L. A., Bogoch, A. L., and Stein, G. (1955). Clinical features of acute inflammation of the pancreas. Arch. intern. Med., 96, 308.

Bolton, C. (1921). Absorption from the peritoneal cavity. J. Path. Bact., 24, 429.
Brouet, G, Chrétien, J., and Modai, J. (1964). Les pléurésies des pancréatites chroniques (à propos de 4 observations d'épauchements pleuraux compliquant ou révélant une pancréatite chronique). J. franc. Méd. Chir. thor., 18, 137.

Byrd, B. F., Jr., and Couch, O. A., Jr. (1955). Pancreatitis with rupture of spleen and haemorrhagic pleural effusion. J. Amer. med. Ass. $157,1112$.

Cachin, J. C., and Battesti, J. P. (1964). Les pleurésies avec élévation du taux de l'amylase pleurale. Poumon, 20, 373.

Case, J. T. (1940). Roentgenology of pancreatic disease. Amer. J. Roentgenol., 44, 485.

Clairmont, P. (1926). Ueber eine bisher nicht beobachtete Form der Pleuritis. Münch. med. Wschr., 73, 1422.

Classen, J. N., and Hooper, J. (1964). Acute pancreatitis and its complications. A review of one hundred and nineteen cases. Amer. Surgn, 30, 391

Clauss, R. H., and Wilson, D. W. (1958). Pancreatic pseudocyst of the mediastinum. J. thorac. Surg., 35, 795.

Coffey, R. J. (1952). Unusual features of acute pancreatic disease. Ann. Surg., 135, 715.

Cornet, E., Dupon, H., and Giraudet, J. (1963). Pleurésies hémorrhagiques d'origine pancréatique. Ann. Chir., 17, 100.

Courtice, F. C., and Steinbeck, A. W. (1951). Effects of lymphatic obstruction and of posture on absorption of protein from peritoneal cavity. Aust. J. exp. Biol. med. Sci., 29, 451.

Cunningham, R. S. (1922). Studies in absorption from serous cavities. IV. On the passage of blood cells and granules of different sizes through the walls of lymphatics in the diaphragm. Amer. J. Physiol., 62, 248.

de Takats, G., and Mackenzie, W. D. (1932). Acute pancreatic necrosis and its sequelae: a critical study of 30 cases. Ann. Surg. 96, 418 .

Dignan, A. P. (1965). Pancreatico-bronchial fistulae. Postgrad. med. J., 41, 158 .

Dumont, A. E., Doubilet, H., and Mulholland, J. H. (1960). Lymphatic pathways of pancreatic secretion in man. Ann. Surg., 152, 403.

Edlin P. (1951). Mediastinal pseudocyst of the pancreas. Case report and discussion. Gastroenterology, 17, 96.

Ende, N. (1960). Studies of amylase activity in pleural effusions and ascites. Cancer (Philad.), 13, 283.

Evans, H. W. (1960). Painless chronic pancreatitis, chylo-ascites and chylothorax. Report of a case. Amer. J. med. Sci., 240, 494.

Farrell, G. E., and Prillaman, P. E. (1964). Pleural effusions in acute pancreatitis. Sth. med.J. (Bgham, Ala.), 57, 505.

Felson-personal communication quoted by Edlin P. (q.v.).

Fishbein, R., Murphy, G. P., and Wilder, R. J. (1962). The pleuropulmonary manifestations of pancreatitis. Dis. Chest, 41, 392.

Florey, H. (1927) Reactions of, and absorption by, lymphatics, with special reference to those of the diaphragm. Brit. J. exp. Path., 8, 479.

Fontaine, R., Lang, G., and Hiebel, G. (1963). A propos de deux cas de kyste nécrotique et d'un cas de pancréatique chronique sclereuse compliques d'epanchements intra-pleuraux de nature hématique. Ann. Chir., 17, 261.

Gambill, E. E., Baggenstoss, A. H., van Patter, W. G., and Power, M. H. (1948). Acute haemorrhagic pancreatitis. Gastroenterology, 11, 371 .

Goldman, M., Goldman, G., and Fleischner, F. G. (1962). Pleural fluid amylase in acute pancreatitis. New Engl. J. Med., 266, 715.

Gross, J. B., and Comfort, M. W. (1957). Hereditary pancreatitis; report on two additional families. Gastroenterology, 32, 829.

Gross, R. J., Null, R., and Loeb, W. (1952). Pseudocyst of the pancreas associated with hydrothorax. Amer. J. Roentgenol., 67, 585.

Hammarsten, J. F., Honska, W. L., and Limes, B. J. (1959). Pleural fluid amylase in pancreatitis and other diseases. Amer. Rev. Tuberc., $79,606$.

Hammouda, A. A. (1967). Case of Demons-Meigs syndrome. Brit. med. J., 1, 414.

Harley, H. R. (1955). Subphrenic abscess, with particular reference to the spread of infection. Ann. roy. Coll. Surg. Engl., 17, 201.

Hart, C. (1904). Die multiple Fettgewebsnekrose. Münch. med. Wschr., 51, 49

Héraud, M., and Guerrin, F. (1959). Pleurésie abondante au cours d'une pancréatite aigue. Arch. Mal. Appar. dig., 48, 1797.

Higgins, G. M., and Graham, A. S. (1929). Lymphatic drainage from peritoneal cavity in dog. Arch. Surg., 19, 453.

Hultén, O. (1928). Beitrag zur Röntgendiagnose der akuten Pankreasaffektionen. Acta radiol. (Stockh.), 9, 222.

Hunt, R. S. (1954). Pancreatico-bronchial fistula. A report on two cases. Brit. J. Surg., 41, 599.

Jones, E. S. (1944). Pancreatic cysts, with report of two unusual cases. J. Indiana med. Ass., 37, 175. 
Judd, E. S., Mattson, H., and Mahorner, H. R. (1931). Pancreatic cysts. Report of forty seven cases. Arch. Surg., 22, 838.

Juniper K., Jr. (1955). Chronic relapsing pancreatitis with associated marked eosinophilia and pleural effusion. Amer. J. Med., 19, 648.

Kalser, M. H., Roth, J. L. A., and Bockus, H. L. (1955). Relapsing pancreatitis with pseudocyst of the pancreas and enzyme-containing pleural effusion. Gastroenterology, 28, 842.

Langeron, P., Prévost, A. G., and Oudar, H. (1959). Pancreatite calcifiante avec obstruction canalaire et hydro-pancréatose. Épanchement pleural à éosinophiles. Presse méd., 67, 2131.

Lemon, W. S., and Higgins, G. M. (1929). Lymphatic absorption of particulate matter through the normal and the paralysed diaphragm: an experimental study. Amer. J. med. Sci., 178, 536.

Lipp, W. F., and Aaron, A. H. (1950). Acute pancreatitis: further observations of value in its recognition. N.Y. St. J. Med., 50, 2043.

MacCallum, W. G. (1903). On the mechanism of absorption of granular materials from the peritoneum. Johns Hopk. Hosp. Bull., $14,105$.

Mahaffey, J. H., Haynes, B. W., Mallams, J., and DeBakey, M. E. (1955). Pseudocyst of the pancreas associated with hydrothorax. Amer. Surgn, 21, 601 .

Meigs, J. V., Armstrong, S. H., and Hamilton, H. H. (1943). A further contribution to the syndrome of fibroma of the ovary with fluid in the abdomen and chest, Meigs syndrome. Amer. J. Obstet. Gynec., 46, 19.

Menville, L. J., and Ané, J. N. (1934). A roentgen study of the absorption by the lymphatics of the thorax and diaphragm of thorium dioxide injected intrapleurally into animals. Amer.J. Roentgenol., $31,166$.

Meyers, S. G., Brown, J. R., Boone, R., and Henderson, H. (1955). Clinical manifestations of pancreatitis. Gastroenterology, 28, 803 .

Miguères, J., Fabre, P., Fregevu, Y., and Azais, Y. (1964). Pleurésie enzymatique au cours d'une pancréatite aigue récidivante. $J$. franc. Mid. Chir. thor., 18, 499.

Modai, J., Hazard, J., and Domart, A. (1965). Épanchements pleuropéritonéaux révelateurs de pancreatites chroniques. Intérêt du dosage de l'amylase dans les épanchements séreux. (A propos de trois observations.) Bull. Soc. méd. Hôp. Paris, 116, 1217.

Moreaux, J., Clot. J.-P., Mercadier, M., and Hepp, J. (1966). Pancréatites et épanchements. Ann. Chir., 20, 413

Muscatello, G. (1895). Ueber den Bau des Aufsaugungsvermögen des Peritonäum. Virchows Arch. path. Anat., 142, 327.

Ochsner, A., and de Bakey, M. (1938). Subphrenic abscess; collective review and analysis of 3608 collected and personal cases. Surg. Gynec. Obstet., 66, 426.

Payr, E., and Martina, A. (1906). Experimentelle Untersuchungen über die Aetiologie der Fettgewebsnekrose und Leberveränderungen bei Schädigung des Pankreasgewebes. Dtsch. Z. Chir., 83, 189.

Perry T. T. (1947). Role of lymphatic vessels in the transmission of lipase in disseminated pancreatic fat necrosis. Arch. Path., 43, 456.
Phillips, S. (1901). A case of fatal pancreatic cyst of enormous size simulating ascites. Trans. clin. Soc. Lond., 34, 53.

Poppel, M. H. (1959). Some migratory aspects of inflammatory collections of pancreatic origin. Radiology, 72, 323.

Roseman, D. M., Kowlessar, O. D., and Sleisenger, M. H. (1960) Pulmonary manifestations of pancreatitis. New Engl. J. Med., 263, 294.

Ruffo, A., Pironti, L., and Massa, G. (1960). Fistola pancreaticopulmonare. Descrizione di un caso. Minerva med., 51, 2537.

Satrazin, A., Le Rohelec, G., Bousquet, O., Naudy, F. P., and Deparis, M. (1965). Pleurésie et syndrome péritonéo-pleural révélant une affection pancréatique chronique. Bull. Soc. méd. Hóp. Paris, 116, 1209.

Saubier, E., Viard, H., and Termet, H. (1962). A propos de deux cas de pseudo-kystes du pancréas a symptomatologie thoracique. Arch. Mal. Appar. dig., 51, 207.

Saunders, S. J., and Lanzkowsky, P. (1956). Haemorrhagic pleural effusion in pancreatitis. S. Afr. med. J., 30, 1069.

Schiepatti, E., and Vernengo, M. J. (1946). El derrame pleural en las pancreatitis agudas. Bol. Soc. argent. Ciruj., 30, 1115.

Sease, C. I. (1956). Bronchial pancreatic fistula. A case report. Virginia med. Mth., 83, 510.

Sharafaev, A. G. (1961). Pleural effusions attending acute pancreatitis. Klin. Med. (Mosk.), 39, 134

Smith, E. B. (1953). Hemorrhagic ascites and hemothorax associated with benign pancreatic disease. Arch. Surg., 67, 52.

Soupault, R. (1958). A propos des faux kystes du pancréas. Mim. Acad. Chir., 84, 678.

Stein, G. N., Kalser, M. H., Sarian, N. N., and Finkelstein, A. (1959) An evaluation of the roentgen changes in acute pancreatitis: correlation with cilnical findings. Gastroenterology, 36, 354.

Traquair, K. (1946). Chylothorax following traumatic pseudocyst of pancreas. Brit. J. Surg., 33, 297.

Trémolières, J., Le Quintrec, Y., Lambling, A., and Carayon, P. (1965). Epanchements pleuraux au cours des pancreatites. Traitement par perfusion intrapleurale d'acide lactique. Bull. Soc. méd. Hóp. Paris, 116, 1231.

Vachon, A., Guillemin, G., Braillon, G., Bady, B., and Ricca, G. (1962). Les pleurésies à enzymes pancréatites. Influence des antienzymes sur leur évolution. (A propos d'ane observation.) antienzymes sur leur evolution.
Arch. Mal. Appar. dig., 51, 1413.

Vachon, M. A., Bady, Mlle., Tête, B., and Levrat, R. (1963). Les pleurésies d'origine pancréatique. Rev. lyon. Méd., 12, 869 .

Warembourg, H., Lekieffre, J., Bertrand, M., and Delbecqie, H. (1966). Epanchement pleural au cours d'une pancréatite subaigue. Lille méd., 11, 467.

Warter, J. Metais, P., Weill, J. P., and Storck, D, (1962). Intérêt de l'étude enzymatique de certains épanchements au cours des maladies du pancréas. Rev. int. Hipat., 12, 1033.

- Moise, R., Asch, L., Storck, D., and Gillet, B. (1963). Nouvelle observation de pleurésie pancréatique. Strasbourg méd., 14, 534

Werner, H. (1942). Pankreatogene Pleuritis. Zbl. inn. Med., 63, 577. 